\title{
Motivations for providing CSR-mediated initiatives in mining communities of Ghana: a multiple-case study
}

\author{
Richard Kwasi Boso*, Sam K. Afrane and Daniel K. B. Inkoom
}

\begin{abstract}
This study used an eclectic multiple-case design to explore what drives three large-scale mining companies' involvement in CSR-mediated development activities, and their philosophical underpinning. The research discovered that although there were nuances between cases in the order in which they rated the strength of 11 potential drivers of CSR, eight of them were important. Three (3) of these were strong drivers - reputation management, pre-emptive anti-regulationism, and pre-existence of local development plans. Five others were moderately strong drivers. The investigations further found that the philosophical underpinnings of the case companies' CSR were based on 'Common-Sense Morality,' a duty-based deontological moral philosophy that is a departure from widely held instrumental positions associated with Egoism. It also identified constrained profitmaximization as the CSR strategy from which their CSR policies emanated.
\end{abstract}

Keywords: Corporate Social Responsibility, Drivers of CSR, Gold mining, Ethical philosophy, Community development, Gold Fields Ghana, AngloGold Ashanti, Newmont Ghana Gold

\section{Introduction}

Why will a profit-making mining firm set aside resources for Corporate Social Responsibility (CSR), a term that symbolises ethical responsibility, moral obligations (Klempner, 2006) and traditional not-for-profit agenda? As in other developing countries, mining companies across the industrial spectrum in Ghana are engaged in a wide variety of social investments ranging from philanthropic donations to more strategic deployment of physical infrastructure for socioeconomic development (Arko, 2013; Boon \& Ababio, 2009; Chatterjee \& Mitra, 2017; GCM, 2012; Hilson, 2014; Ofori \& Hinson, 2007; Manteaw, 2008; Ofori \& Hinson, 2007; Temeng \& Abew, 2009). They claim a commitment to building on the underlying principles of the Global Mining Initiative (GMI) as well as the Ghana Extractive Industries Transparency Initiative (GEITI) (Nguyen-Thanh \& Schnell, 2009) to contribute projects that yield socio-economic returns to the communities (GCM, 2008a, 2008b). Between 2004 and 2013, members of the Ghana Chamber of Mines (GCM) directly contributed approximately $1 \%$ of

\footnotetext{
* Correspondence: richboso@gmail.com

Department of Planning, Kwame Nkrumah University of Science and Technology, Kumasi, Ghana
}

their gross revenues (averaging US\$8.6 million per annum) through CSR initiatives to their host communities (GCM, 2014; Temeng and Abew, 2009).

But what motivates such beyond-legal-requirement interests, and what moral philosophies underprop these drivers? The debate in extant literature have tended to pit altruism against self-interest as possible motivations for CSR. It is to contribute to unravelling this perplexity (Capaldi, 2016) that this study set out to investigate the drivers, philosophies and strategies of CSR involvement among large multinational mining companies operating in Ghana. This question is not only important in anticipating the quality of corporate-community engagement process miners deploy in furtherance of CSR initiatives, but potentially fills the knowledge gap on the ethicality of CSR in developing country context - knowledge that can potentially aid communities to better negotiate and optimise their 'rights' around the benefits of mining in more sustainable ways.

The paper, based on a broader research for a doctoral thesis, begins with a brief review of literature on the subject, followed by the research methodology employed in carrying out the research. It concludes 
with a summary of findings, after reporting and discussing result of the empirical investigation in the light of normative arguments associated with relevant moral philosophies.

\section{Gold mining in Ghana}

Ghana is the second largest producer of gold in Africa behind South Africa, and a leading exporter of bauxite, diamonds, and timber (Aryeetey et al., 2005). In July 2014, International Monetary Fund (IMF) estimates put Ghana's population at 25.8 million, with an annual growth rate of $2.55 \%$. Its total area is 238,555 sq. $\mathrm{km}$, i.e. comparable to Uganda, the Great Britain, Romania and the US State of Oregon, (Sources: Encyclopaedia Britannica; IMF, 2015). Reforms in the Ghanaian mineral laws and policies from the 1980s led to a rapid growth of Ghana's mining economy. According to the Ghana Chamber of Mines (2008b), the mining sector brought in US $\$ 5$ billion in foreign direct investment (FDI) between 1983 and 2002. As a result, mine production saw a massive increase over the previous three decades on the back of gold production (Yankson, 2010). The mining sub-sector therefore grew at rates of 5.5 and $8 \%$ in 2008 and 2013 respectively. For instance, it contributed 33-49\% per annum of Ghana's foreign exchange earnings between 2000 and 2011 (GCM, 2014). Mining and quarrying currently contribute an average of about 5\% to annual GDP, having improved from $1.3 \%$ in 1991 to $6.6 \%$ in 2007 (GCM, 2008). Major mining firms and mine support service firms directly employed over 24,000 persons while artisanal or small-scaled miners employed an estimated 600,000 by the end of 2007 (GCM Ghana Chamber of Mines 2008b).

Mining activities in Ghana date back more than two millennia when its gold reached the Mediterranean by camel caravan across the Sahara Desert (Yelpaala \& Ali, 2005). The primary reason for this mineral wealth is the fact that Ghana's geological setting falls within the mineral-laden Precambrian Shield of West Africa that are associated with Proterozoic, Birimian and Tarkwaian rocks, and the majority of gold produced in Ghana comes from Birimian rocks (Ghana Minerals Commission, 2010). Gold, diamond, bauxite, manganese, salt and other minerals such as granite, gravels, sand and clay are the most commonly mined, though the most important in terms of economic viability, foreign exchange earnings and employment generation are gold, diamond, manganese and bauxite, with gold alone contributing more than 90\% (Aryeetey et al., 2004; Gough \& Yankson, 2012; Yankson 2010).

Historically, most gold mining before the mid-nineteenth century was alluvial, with miners recovering the gold from stream and riverbeds. By mid-15th Century, Portuguese navigators were shipping Ghana's gold directly to Europe.
Records of the Old Bono (late 13th Century) and Ashanti (15th Century) kingdoms came along with their goldsmiths much famed for their distinctive ornaments (Effah-Gyamfi, 1979). Large-scale exploration and gold mining in Ghana began shortly after 19th Century European colonisation. In 1877, the first European gold concession was issued in Tarkwa, South-Western Ghana and 20 years later Gold Fields Corporation Ltd was founded. Other major mines that were started around the same time include Abosso (1882); Bibiani (1901); Prestea (1903); and Tarkwa (1909) (Yelpaala \& Ali, 2005). Modern underground gold mining however began around 1860 when European concessionaires imported heavy machinery and began working in the south-western areas of present-day Ghana. A group of Europeans explorers discovered the richest deposit, the Obuasi mine and sold their rights to Edwin A. Cade, the founder of Ashanti Goldfields Corporation (AGC) now AngloGold Ashanti (AGA). Since then, most mining has been pursued as a large-scale venture, necessitating significant capital investment from foreign investors (Aryeetey et al., 2004).

\section{Profile of cases \\ Case 1 profile: Gold Fields Tarkwa Mine and host community}

Gold Fields Ghana Limited (GFG), incorporated in Ghana in 1993, currently operates the highest gold producing mine in Ghana, and the highest gold producer in the Gold Fields International portfolio. The Tarkwa mine, sited on approximately $20,825 \mathrm{ha}$. of land, is located in the largest mineral mining enclave in Africa, south western Ghana. It has a Life of Mine (LoM) that potentially extends to 2034 (GFG, 2014). GFG spent US\$32 million on 1,747 employees in 2008, increasing it to US\$64 million on 2,769 employees by 2013. The mine is hosted by the TarkwaNsuaem Municipality (TNMA) in the Western Region of Ghana between latitudes $4^{\circ} 5^{\prime} \mathrm{N}$ and $5^{\circ} \mathrm{N}$ and between longitudes $1^{\circ} 45^{\prime} \mathrm{W}$ and $2^{\circ} 10^{\prime} \mathrm{W}$. Politically, TNMA's land area of 2,354 sq. $\mathrm{km}$ is administered by the Tarkwa urban council and five (5) zonal councils made up of 438 peri-urban and rural communities. Its 100,000 (approx.) population has $48.4 \%$ females, with $68 \%$ of its economy being agricultural while the rest engage in informal sector commerce and hospitality. Its financial, educational, services and road infrastructure is underdeveloped, although it hosts one public university.

Case 2 profile: AngloGold Obuasi Mine and its host community AngloGold Ashanti Ltd (AGA), a global gold producer with 21 operations on four continents, was formed in a merger between AngloGold Corporation and Ashanti Goldfields Corporation (AGC) in 2004. It is listed on the New York, Johannesburg, Accra, London and Australian stock exchanges, as well as on the Paris and Brussels bourses. In Ghana, AngloGold Ashanti (AGA) has the 
richest mining site, by ore reserves. AGA's antecedent, AGC had operations spanning more than a century in Obuasi, and currently operates a second smaller mine at Iduapeiem in the Western Region of Ghana (AGA, 2007). Obuasi is the capital town of the Obuasi Municipality, $64 \mathrm{~km}$ southwest of the Ashanti regional capital of Kumasi between latitude $5.35 \mathrm{~N}$ and $5.65 \mathrm{~N}$ and longitude $6^{\circ} 35^{\prime} \mathrm{N}$ and $6^{\circ} 90^{\prime} \mathrm{N}$. and covers a land area of $1,624 \mathrm{~km}^{2}$. Its 53 communities have a population of 168,600 (approx.), 58\% of whom are females. The predominantly urban population has $74.3 \%$ employed in the private informal sector, followed by in the private sector (GSS, 2012).

Case 3 profile: Newmont Ahafo Mine and its host community Denver-headquartered Newmont Mining Corporation a gold producer with significant assets in the United States, Australia, Peru, Indonesia, Ghana, Canada, New Zealand and Mexico, wholly owns Newmont Ghana Gold Ltd (NGGL) Ahafo mine in the Brong-Ahafo administrative region of Ghana (and the Akyem operation in the Eastern Region), which started work 2002 but started production at the bigger Ahafo and Akyem in 2006 and 2013 respectively). Newmont is currently the second highest gold producer in Ghana with an annual production of $442,000 \mathrm{oz}$. As of July 2014, it had a total number of 4,400 employees and contractors. NGGL Ahafo mine is located in the Asutifi North District Assembly (ANDA), some $50 \mathrm{~km}$ south of the Brong Ahafo region capital of Sunyani, between latitudes $6^{\circ} 40^{\prime}$ and $7^{\circ} 15^{\prime} \mathrm{N}$ and Longitudes $2^{\circ} 15^{\prime}$ and $2^{\circ}$ $45^{\prime} \mathrm{W}$. The district's predominantly rural population lies within the wet semi-equatorial zone covering a land surface area of $1500 \mathrm{~km}^{2}$ (approx.) and had under-developed social infrastructure.

\section{Drivers of CSR and their Philosophical Underpinnings - A Literature Review The Concept of CSR}

Corporate Social Responsibility (CSR) remains notoriously difficult to define despite a growing scholarly interest in the subject (e.g. Garriga \& Mele, 2004; WBCSD, 2000; van Marrewijk, 2003). Jones (1980, p. 59) conceives it as "the notion that corporations have an obligation to constituent groups in society other than stockholders and beyond that prescribed by law or union contract..." Despite the conceptual nuances, some common ground is widely acknowledged in the definition of CSR (Moon, 2002a; SustainAbility, 2004; van Marrewijk, 2003). These emphasise the 'beyond [legal] compliance,' 'voluntariness,' 'development' and 'stakeholder' constructs of CSR. In view of its comprehensiveness, applicability to private, public and third sector organisation, and suitability for conceptualising
CSR in development context of the current study, this paper defines CSR as the roles an organisation performs for the benefits of its perceived stakeholders usually on moral grounds, and beyond legal requirements - which do not necessarily contribute to the attainment of short-term organisational goals.

\section{The Case for CSR}

The record of big business' contributions to socioeconomic development in Africa is mixed. There is voluminous evidence of the benefits of business in developing countries (e.g. Australian Government, 2006; IBLF, 2002; Ismail, 2009; SustainAbility, 2004; Visser, 2005a, 2005b) just as there are detriments stretching back for centuries (e.g. ActionAid, 2006; Transparency International, 2005). This schism notwithstanding, there is general agreement that the private sector remains one of the best placed institutions to make a significant contribution towards development, often couched in the CSR mould (Govindan et al., 2014; IBLF, 2002), and seen as a way to plug the governance gaps created by weak, corrupt, or underresourced governments that fail to adequately provide social services. Matten and Moon (2008) see this as part of a wider trend in developing countries with weak institutions and poor governance, in which responsibility is often delegated to private actors like family, religion and business, a position supported by Blowfield and Frynas (2005), Blowfield (2003) and (WBCSD, 2000). Moon (2002b) believes that this is part of a broader political shift towards new governance approaches, where governments are increasingly seeking to share responsibilities with the broader society. Moon et al. (2005) cite this as an example of corporations acting in a civic republicanism mode.

\section{Criticisms of CSR}

Perhaps the most popular critic of CSR is Friedman who argued that CSR could weaken the girdle of freedom, since "the only social responsibility of business [is] to use its resources and engage in activities designed to increase its profits so long as it stays within the rules of the game" (Friedman, 1970, p. 32). His position is shared by others (e.g. Albrechtsen, 2006; Henderson, 2001; Husted \& de Jesus Salazar, 2006; Lantos, 2002). Lantos (2002) appear more accommodating of CSR, provided firms "act strategically" (Lantos, 2002, p. 207). By this, Lantos (2002) envisioned an exclusively instrumental CSR when he delineated strategic CSR from altruistic CSR. He averred that the former is not a legitimate role of publicly-owned businesses and that it is immoral on the grounds that such CSR 
breaches shareholder property rights, unfairly confiscating stockholder wealth, ...spends money for the general good at the possible expense of those for whom the firm should be caring, notably employees and customers (Lantos, 2002, p. 205).

Besides Friedman's (1970) criticisms on neoliberal grounds, critiques of voluntary CSR have been generated within the development literature. Jenkins (2005) questions whether CSR can play a significant role in poverty reduction, arguing much like Frynas (2005) that the current CSR agenda in the global arena fails to address issues of governance and the negative macro-level effects that multinational companies create. They argues that a focus on CSR tends to divert attention from broader political, economic and social solutions for developmental problems. Other scholars similarly reject the adequacy of voluntary corporate codes of conduct to effectively restrain the damage done by MNCs in developing countries, let alone act as a force for good. For example, Garvey and Newell (2005) argue that more attention should be paid to a number of state, corporation, and community-related factors critical for the effectiveness of strategies aimed at enhancing corporate accountability to the poor. Further, Graham and Woods (2006) aver that selfregulation by MNCs are not enough and that "Government action ... remains vital to effective regulation," a position shared by Imani Development (2009) and Prasad (2004).

\section{Drivers for CSR Involvement}

Motivations for adopting CSR policies have been, and continue to be interrogated in the CSR discourse. The forces that pressure or incentivise corporations to adopt CSR include civil society's increased focus on human rights (Govindan et al., 2014; Utting, 2005), community concerns for social justice (Gardiner et al., 2003) as well as the rise of global communications and media power, and the emergence of regulation through standardization of social performance expectations (Govindan et al., 2014). Pressure from shareholder activists, lenders and financial institutions' initiatives and governance gaps (Matten \& Moon 2008) have also contributed to driving the CSR agenda at the global, and sometimes, at the state level.

It is obvious that despite varying degrees of objection to CSR (e.g. Friedman, 1970; Lantos, 2001), there are many drivers of CSR (Muthuri, 2007), even if most of these are instrumental and represent the business case for CSR (WBCSD, 2002). According to Kurucz et al. (2008), these constitute a proposition for value creation in the general areas of cost and risk reduction, profit maximisation and competitive advantage, reputation and legitimacy, and synergistic value creation. This will typically rest on one or a combination of the following: human resources management, brand differentiation, license to operate and diverting attention from corporate complicities in unethical behaviours (WBCSD, 2002).

In the specific domain of mineral mining, empirically tested drivers of CSR are lacking. Yankson (2010) avers that large-scale companies (especially in developing world context) are motivated to provide CSR-mediated initiatives to their host communities in order to gain or maintain access to concessions, secure congenial work environment, or promote their reputation enhancement agenda, a position shared with Frynas (2005) and Gough \& Yankson (2012). Amaeshi et al. (2006) and Kemp et al. (2012) have also shown that industry peer mimicry could drive CSR involve. Thus, from a Stakeholder Theoretical stand point, the expectations, interests and power of internal (e.g. financiers/lenders, employees, industry peers) and external stakeholders (e.g. governments, host communities, civil society, media) remain a rich site for empirical research, especially in the Ghanaian mining context.

\section{Moral Philosophies Underpinnings of CSR}

One moral philosophical doctrine or the other underpins the case for CSR. Cavanagh et al. (1981) described a moral framework relevant to CSR that includes three basic moral theories - utilitarian theories, theories of right and theories of justice - for analysing the use of political power in organisational settings. The framework was used to study moral dilemmas in areas such as managerial conflict of interest and personal integrity (Fritzsche \& Becker 1984) and the relationship between managerial behaviour and ethical philosophy (Premeaux \& Mony 1993; Premeaux, 2004). These and similar studies have considered ethicomoral issues in more general managerial terms than the more CSR-specific framework proposed by Lantos (2002) in his three-strand moral underpinnings of CSR namely, teleological (or consequence-based), deontological (or duty-based) and virtue-based theories of philosophies.

Empirical studies on the relation between philosophical moral theories and the ethical content of business activities have mainly concentrated on the ethical decisionmaking of managers. Some investigations suggest that managers act in accordance with Utilitarian moral theory (Fritzsche \& Becker, 1984; Premeaux \& Mony, 1993; Premeaux, 2004). However, Frederiksen (2009) concluded that CSR policies were based on common-sense morality.

Frederiksen (2009) further opined that it is important to determine whether any moral theory of CSR is a minimalistic or a more demanding moral theory. He argues that these differences have a major impact on the design of the companies' CSR policies. On this basis, he proposed a four-component framework-egoism, 
libertarianism (minimalistic), utilitarianism and common sense morality (demanding) - for analysing CSR philosophies.

\section{Egoism}

Moral egoists believe that the morally correct action is the one that maximises the good for the moral agent, i.e., a company will act in its own self-interest (Reidenbach \& Robin, 1990; Crane \& Matten, 2007). Thus, a company ought to do good (or refrain from doing harm) only if it is good for the company, which in this context, will mean profit maximisation.

\section{Libertarianism}

Libertarians believe in the existence of negative rights like freedom of speech, freedom of religion, freedom from coercion etc., but not in positive duties, like donating to charity. It might be a good thing to help the poor, but one has no moral obligation to do so (Nozick, 1974). In relation to CSR, libertarians believe that companies have no moral obligation to positively help others; they are only morally obligated not to violate people's negative rights.

\section{Utilitarianism}

Utilitarians believe that moral agents have to always promote the best possible outcome seen from an impartial perspective. That is to maximise the total sum of happiness (Singer, 1970; Smart, 1973). In relation to CSR, Utilitarians believe that companies have a moral obligation to promote the best possible outcome. Empirically, the utilitarian position appears very demanding, suggesting that companies use a great deal of their resources to help the poor, sick and hungry around the world (Singer, 1970).

\section{Pragmatism}

Supporters of pragmatic or common-sense morality believe in the existence of both negative rights and positive duties. In relation to CSR, companies have a moral obligation not to violate others rights and that they also have positive duties towards certain groups, such as those who are closely related to the company. This orientation is identical to Kagan's (1989) 'ordinary morality.'

\section{Method}

\section{Research design, Sampling, Data Collection and Analysis}

Based on a pragmatic research philosophy (Creswell, 2007; Howe, 1988, 1992; Miller et al., 2008; Mkansi \& Acheampong, 2012; Saunders et al., 2007; Tashakkori \& Teddlie, 1998), the study was designed as an eclectic multiple-case study. That is, it employed a mixed method comprising quantitative and qualitative data collection and analytical strategies. By using a multiple-case instead of a single-case, a "logic of replication" Yin (2003), p. 37, was attempted. It also improves the degree of external generalisability of conclusions drawn).

The collection of primary data was preceded by the collection and analysis of secondary data. This informed the kinds and amounts of primary data gathered. On the basis of their annual gold production volumes, number of employees and gross revenues in the five (5) period of 2009-2013, the study selected the three largest gold mines in Ghana and their respective host communities. Using semi-structured questionnaire and interview guides, 36 key informants were interviewed (See Table 1).

The informants were purposively selected using a combination of referrals, snowballing and reference to lists of organisational portfolios. The interviews were sound-recorded and transcribed for subsequent case write-ups, coding and analyses (Miles \& Huberman, 1994). Key CSR personnel from the mining companies were required to rate how much 11 potential drivers of CSR drove their respective companies' CSR on a sevenpoint Likert-like scale. The mean scores per company were interpreted thus: $1.0-3.0=$ weak driver; $3.1-5.0=$ moderately strong driver; and $5.1-7.0=$ strong driver of CSR involvement.

The analytical framework used in the assessment of moral philosophical underpinnings of CSR was based on Frederiksen (2009). Two questions were put to key CSR manager. The first was based on a scenario of moral dilemma adapted from Frederiksen (2009). The CSR managers were required in a second, an open-ended question, to indicate the most likely decisions their respective companies will take when faced with the similar dilemmas (in a structured question item), after which they were required to give a brief rationale for their decisions (in an open-ended question item). Further, CSR managers were required to rate the extent to which they thought their respective companies would demonstrate moral responsibility to 17 stakeholders of differing proximities. The seven-point Likert-type scale used for the ratings was interpreted as 1.0-3.0 for Marginal Moral

Table 1 Categories of key informants

\begin{tabular}{lll}
\hline Case & Type of informant & No. of Informants \\
\hline GFG Tarkwa (Case 1) & Company Management & 4 \\
& Community Leaders & 5 \\
& State Institutions & 3 \\
AGA Obuasi (Case 2) & Company Management & 3 \\
& Community Leaders & 7 \\
& State Institutions & 4 \\
NGGL Ahafo (Case 3) & Company Management & 3 \\
& Community Leaders & 5 \\
& State Institutions & 2 \\
Total & & 36 \\
\hline
\end{tabular}


Responsibility; 3.1-5.0 for Limited Moral Responsibility; and 5.1-7.0 for High Moral Responsibility.

\section{Data reliability, Validity of Conclusions and Research Ethics}

Data reliability, the extent to which data collection techniques yield consistent findings, was supported in a number of ways: data triangulation (Saunders et al., 2007); reliability testing for structured question items using Crombach's Alpha (Crombach (1951) in Tavakol \& Dennick, 2011); and pre-testing of data collection instruments on residents and AGA staff in three suburbs of Obuasi who were deemed similar in characteristics to prospective respondents.

In this research, the extent to which research findings are really about what they profess to be about, i.e. validity of general conclusions (Saunders et al., 2007) rested on the internal consistency between explanatory relationships, contextual parameters, and data generated from multiple sources (Denzin \& Lincoln, 1994). It was based on a deemphasis of the method-theory antimony (Bourdieu, 1992) such that the primary test of validity rested on the consistency between theoretical constructs and the data. Since such validity depended of data reliability, strong emphasis was laid on ensuring a high level of data reliability, as explained earlier.

The research was guided by standard research ethics recommended in the 2010 amendment of the American Psychological Association (APA) ethical code of researchers' conduct (APA, 2010) These were related to participants' welfare and dignity such as their prior informed consent, anonymity, confidentiality, and right to withdraw from participation at any time in the research process without sanctions, as well as researcher candour.

\section{Results and Discussion}

\section{Key Drivers of CSR among Mining Companies in Ghana}

The literature is replete with drivers of CSR involvement by multinational mining firms of varying salience in varying contexts. Table 2 shows how key CSR personnel perceive such salience. It is indicated by the scores of how the 11 potential drivers impacted their respective companies' CSR policy and practices.

In reference to the Combined scores for the case companies, respondents scored company reputation (i.e., the need to procure, protect and promote company reputation), pre-emptive anti-regulationism (i.e. the need to pre-empt inimical legal and regulatory regimes) and pre-existence of [compatible] development) among the strong drivers (Scores: 5.6 - 7.0). Conversely, average scores for three drivers - Legal Requirement, Financial Strength and Tax Incentive - were weak (Score: 1.4 - 2.2), indicating that these may not be drivers, or at best, only weak drivers,
Table 2 Mean scores for drivers of CSR involvement

\begin{tabular}{|c|c|c|c|c|c|}
\hline \multirow[t]{2}{*}{ No. } & \multirow[t]{2}{*}{ Potential Driver of CSR } & \multicolumn{4}{|l|}{ Case } \\
\hline & & $\overline{\mathrm{GFG}}$ & AGA & NGGL & Combined \\
\hline 1. & $\begin{array}{l}\text { Expectations of Internal } \\
\text { Stakeholders }\end{array}$ & 3.0 & 4.7 & 3.0 & 3.6 \\
\hline 2. & $\begin{array}{l}\text { Expectations of Supply Chain } \\
\text { Partners }\end{array}$ & 2.0 & 6.5 & 3.0 & 3.8 \\
\hline 3. & Industry Peer Pressure/Mimicry & 2.0 & 5.3 & 2.0 & 3.1 \\
\hline 4. & Expectations of Host Community & 2.2 & 6.3 & 4.0 & 4.2 \\
\hline 5. & Need for Legal Compliance & 1.0 & 4.7 & 1.0 & 2.2 \\
\hline 6. & Pre-emptive anti-regulationism & 6.5 & 6.7 & 6.0 & 6.4 \\
\hline 7. & Bitter Sanction Experience(s) & 4.0 & 4.3 & 4.0 & 4.1 \\
\hline 8. & Tax Incentives & 1.0 & 2.3 & 1.0 & 1.4 \\
\hline 9. & Company Reputation & 6.0 & 7.0 & 7.0 & 6.7 \\
\hline 10. & Financial Strength of company & 2.0 & 3.0 & 1.0 & 2.0 \\
\hline 11. & $\begin{array}{l}\text { Compatibility with development } \\
\text { plans }\end{array}$ & 7.0 & 3.7 & 6.0 & 5.6 \\
\hline
\end{tabular}

in the Ghanaian large-scale mining context. The remaining potential drivers tested indicated moderate levels of salience, ranging between 3.1 and 4.2 in average scores.

Within cases, the scores were more nuanced (See Table 3). The three strong drivers identified in the 'Combined,' featured within all cases, except AGA. GFG also departed from the norm by scoring Pre-existing Development Plans as the strongest driver.

In AGA, three more strong drivers were identified in addition to the first two: the expectations of supply chain partners, expectations and/or agitations of host communities, and pressure from and mimicry of industry peers $(5.3-6.7)$. All the three cases rated the desire to avoid future bitter sanctions from regulators among moderately strong drivers. In GFG, this was the only moderately strong driver, but it was rated similarly along with expectations and/or agitations of host communities in NGGL (Score: 4.0). AGA however showed a marked difference in that it ranked expectations of internal stakeholders (i.e. managers, employees, shareholders etc.) and requirement for legal compliance (Score: 4.7) above 'bitter sanctions', while ranking 'compatibility with local development plans' a step below it. Overall, host community expectations (4.2); bitter experience with regulators (4.1); supply chain partners' expectations (3.8); internal stakeholders' expectations (3.6); and industry peer pressure/mimicry (3.1) were rated as moderate drivers of CSR in descending order.

In GFG, as many as eight (8) potential drivers were thought to be weak or none determinants of CSR involvement: internal stakeholders' expectations, (Score: 3.0) and host communities' expectations (Score: 2.2). These were followed by 'bitter sanction, 'industry peer pressure, supply chain partners' expectations and a company's unique 
Table 3 Strengths of drivers of CSR involvement by case

\begin{tabular}{|c|c|c|c|}
\hline$\overline{\mathrm{GFG}}$ & AGA & NGGL & Combined \\
\hline \multicolumn{4}{|l|}{ Strong Drivers } \\
\hline $\begin{array}{l}\text { - Compatibility with } \\
\text { development plans (7.0); } \\
\text { - Pre-emptive anti- } \\
\text { regulationism (6.5); } \\
\text { - Company reputation (6.0) }\end{array}$ & $\begin{array}{l}\text { - Company reputation (7.0); } \\
\text { - Pre-emptive anti-regulationism (6.7); } \\
\text { - Supply chain partners' } \\
\text { expectations (6.5); } \\
\text { - Host community expectations (6.3); } \\
\text { - Peer pressure/mimicry (5.3) }\end{array}$ & $\begin{array}{l}\text { - Company reputation (7.0); } \\
\text { - Pre-emptive anti-regulationism (6.0); } \\
\text { - Compatibility with development } \\
\text { plans }(6.0)\end{array}$ & $\begin{array}{l}\text { - Company reputation (6.7); } \\
\text { - Pre-emptive anti-regulationism } \\
\text { (6.4); } \\
\text { - Compatibility with development } \\
\text { plans (5.6) }\end{array}$ \\
\hline \multicolumn{4}{|l|}{ Moderately Strong Drivers } \\
\hline $\begin{array}{l}\text { - Bitter experience with } \\
\text { regulators }(4.0) ;\end{array}$ & $\begin{array}{l}\text { - Internal stakeholders' } \\
\text { expectations (4.7); } \\
\text { - Legal compliance (4.7); } \\
\text { - Bitter experience with } \\
\text { regulators (4.3); } \\
\text { - Compatibility with } \\
\text { development plans (3.7); }\end{array}$ & $\begin{array}{l}\text { - Host community expectations/ } \\
\text { agitations ( } 4.0)_{i} \\
\text { - Bitter experience with } \\
\text { regulators (4.0); }\end{array}$ & $\begin{array}{l}\text { - Host community expectations/ } \\
\text { agitations (4.2); } \\
\text { - Bitter experience with } \\
\text { regulators (4.1); } \\
\text { - Expectations/pressure from } \\
\text { supply chain partners (3.8) } \\
\text { - Expectations/agitations of } \\
\text { internal stakeholders (3.6) } \\
\text { - Industry codes as pressure/ } \\
\text { mimicry (3.1) }\end{array}$ \\
\hline \multicolumn{4}{|l|}{ Weak Driver } \\
\hline $\begin{array}{l}\text { - Internal stakeholders' } \\
\text { - } \text { Host communions (3.0) } \\
\text { - Bitter expectations 2.2); } \\
\text { - Peer pressure/mimicry (2.0); } \\
\text { - Supply chain expectations (2.0); } \\
\text { - Unique financial strength (2.0); } \\
\text { - Legal compliance (1.0); } \\
\text { - Tax incentive (1.0) }\end{array}$ & $\begin{array}{l}\text { - Company's relative better } \\
\text { financial muscle (3.0) } \\
\text { - Tax incentives (2.3) }\end{array}$ & $\begin{array}{l}\text { - Internal stakeholders' } \\
\text { expectations (3.0); } \\
\text { - Supply chain partners' } \\
\text { expectations (3.0) } \\
\text { - Peer pressure/mimicry (2.0) } \\
\text { - Legal compliance (1.0); } \\
\text { - Tax incentive (1.0); } \\
\text { - Unique financial strength (1.0) }\end{array}$ & $\begin{array}{l}\text { - Legal compliance (2.2); } \\
\text { - Unique financial strength (2.0); } \\
\text {-Tax incentive (1.4); }\end{array}$ \\
\hline
\end{tabular}

financial position (Score: 2.0), legal compliance and hope of tax incentives at the very bottom. In AGA, unique financial position and tax incentives were the only potential drivers featured rated as weak drivers. In NGGL, three potential drivers, namely legal compliance, tax incentives and unique financial position (Score: 1.0) were ranked weakest behind the expectations of internal stakeholders (Score: 3.0) and industry peer pressure and mimicry (Score: 2.0). Taken together, three (3) potential drivers made the list for weak or non-drivers of CSR involvements by the companies under investigation: legal compliance, unique financial strength and tax incentive.

The foregoing observation were expected to be underpropped by one or more moral philosophies, to which we turn attention in the next section.

\section{Moral Philosophical of Case Companies}

In the scenario running, all the respondents thought their companies would provide assistance to their local communities rather than to the same or twice as many people in distant non-land-take locations. Not even a five-fold hike in the number (in an attempt to raise the moral stakes of decision making) of distant potential beneficiaries changed the moral decision of the respondents. That is to say, no respondent thought that, based on their companies' CSR policies, they will build borehole(s) in distant communities. However, they were not indifferent about where a borehole was built; neither were they indifferent about whether their respective companies built a borehole in the first place. The ratings of moral responsibility the respondents felt toward the 17 distant and proximate stakeholders are presented in Table 4.

In all three cases, shareholders, lenders, adversely affected (e.g. victims of land-take, communities whose water sources were polluted) and company employees were ranked highest (Score: 6.0 - 7.0), even though there were some nuances between them with respect to their mean scores (See Table 5).

The order was the same for GFG and NGGL, where employees, lenders and the adversely affected were ranked second, third and fourth respectively below shareholders. These two companies equally ranked traditional chiefs and local charity as the next highest (Score: 5.5 - 6.5) in the High Responsibility category as well. In AGA, a major departure from the other two companies was that it elevated Employees to the same highest rank as Shareholders while ranking local charity as the next most important stakeholder after the top four (Score: 6.0). NGGL was the only one that added customers and business association (i.e. Ghana Chamber of Mines) to this category. Overall, respondents unequivocally ranked moral responsibility toward shareholders highest within, between and across cases (Score: 7.0). They were followed by lenders, adversely affected and employees 
Table 4 Mean scores of mining companies' moral obligation

\begin{tabular}{llcccc}
\hline No. & Stakeholder & GFG & AGA & NGGL & Combined \\
\hline 1. & Shareholders & 7.0 & 7.0 & 7.0 & 7.0 \\
2. & Any Needy Anywhere & 3.0 & 2.0 & 1.5 & 2.2 \\
3. & Suppliers & 5.0 & 4.5 & 4.0 & 4.5 \\
4. & Local Charity & 5.5 & 6.0 & 6.0 & 5.8 \\
5. & Employees & 6.0 & 7.0 & 6.5 & 6.5 \\
6. & Competitors & 1.5 & 1.0 & 1.0 & 1.2 \\
7. & Customers & 5.0 & 5.0 & 5.5 & 5.2 \\
8. & Local Government & 4.0 & 4.0 & 5.0 & 4.3 \\
9. & National Charity & 3.0 & 3.0 & 2.5 & 2.8 \\
10. & Local Sports & 4.0 & 5.0 & 4.0 & 4.3 \\
11. & National Sports & 3.0 & 2.5 & 2.0 & 2.5 \\
12. & Lenders & 7.0 & 6.5 & 7.0 & 6.8 \\
13. & Traditional Chiefs & 6.0 & 5.0 & 6.5 & 5.8 \\
14. & National Government & 3.0 & 2.5 & 2.0 & 2.5 \\
15. & Regulators & 2.0 & 2.0 & 1.5 & 1.8 \\
16. & Adversely Affected & 7.0 & 6.5 & 7.0 & 6.8 \\
17. & Business Association & 4.0 & 4.5 & 5.5 & 4.7 \\
\hline
\end{tabular}

(Score: 6.5-6.8) in the middle tier; and local charity, traditional chiefs and customers (Score: 5.2-5.8) in the lower tier of the High Responsibility category.

For 'Limited Responsibility', the cases displayed varied stakeholders by way of numbers and order of importance. In GFG, supply chain partners (i.e. suppliers and customer, Score: 5.0) were ranked higher than two local entities (i.e. local government and local sporting clubs) and business association (Score: 4.0). In AGA, the respondents ranked six stakeholders such that customers, local sporting clubs and traditional chiefs were highest (Score: 5.0); suppliers and business association were second with a score of 4.5 , while local government took the last place in the category with a score of 4.0. Finally, NGGL showed greater moral responsibility towards the local government (i.e. District Assembly) at a score of 5.0, than both their suppliers and local sporting clubs at a score of 4.0. Overall, the three cases ranked moral responsibility towards the Chamber of mines highest in the Limited Responsibility category (Score: 4.7), followed by suppliers (Score: 4.5$)$ and the duo of local government and local sports in the last place (Score: 4.3).

All cases featured exactly the same 11 out of the 17 stakeholders in the 'High Responsibility' and 'Limited'

Table 5 Rankings of moral responsibility towards company stakeholders

\begin{tabular}{|c|c|c|c|}
\hline$\overline{\mathrm{GFG}}$ & AGA & NGGL & Combined \\
\hline \multicolumn{4}{|l|}{ High Responsibility } \\
\hline - Shareholders (7.0) & - Shareholders (7.0) & - Shareholders 7.0) & - Shareholders (7.0) \\
\hline - Lenders (7.0) & - Employees (7.0) & - Lenders (7.0) & - Lenders (6.8) \\
\hline - Adversely Affected (6.5) & - Lenders (6.5) & - Adversely Affected (7.0) & - Adversely Affected (6.8) \\
\hline - Employees (6.0) & - Adversely Affected (6.5) & - Employees (6.5) & - Employees (6.5) \\
\hline - Traditional Chiefs (6.0) & - Local Charity (6.0) & - Traditional Chiefs (6.5) & - Local Charity (5.8) \\
\hline \multirow[t]{3}{*}{ - Local Charity (5.5) } & & - Local Charity (6.0) & - Traditional Chiefs (5.8) \\
\hline & & - Customers (5.5) & \\
\hline & & - Business Assoc. (5.5) & \\
\hline \multicolumn{4}{|l|}{ Limited Responsibility } \\
\hline - Suppliers (5.0) & - Customers (5.0) & - Local Govt. (5.0) & - Customers (5.2) \\
\hline - Customers (5.0) & - Local Sports (5.0) & - Suppliers (4.0) & - Business Assoc. (4.7) \\
\hline - Local Government (4.0) & - Traditional Chiefs (5.0) & - Local Sports (4.0) & - Suppliers (4.5) \\
\hline - Local Sports (4.0) & - Suppliers (4.5) & & - Local Government (4.3) \\
\hline \multirow[t]{2}{*}{ - Business Assoc. (4.0) } & - Business Assoc. (4.5) & & - Local Sports (4.3) \\
\hline & - Local Govt. (4.0) & & \\
\hline \multicolumn{4}{|l|}{ Minimal Responsibility } \\
\hline - National Charity (3.0) & - National Charity (3.0) & - National Charity (2.5) & - National Charity (2.8) \\
\hline - National Sports (3.0) & - National Sports (2.5) & - National Sports (2.0) & - National Sports (2.5) \\
\hline - National Govt. (3.0) & - National Govt. (2.5) & - National Govt. (2.0) & - National Govt. (2.5) \\
\hline - Any Needy (3.0) & - Any Needy (2.0) & - Any Needy (1.5) & - Any Needy (2.2) \\
\hline - State Regulators (2.0) & - Regulators (2.0) & - Regulators (1.5) & - Regulators (1.8) \\
\hline - Competitors (1.5) & - Competitors (1.0) & - Competitors (1.0) & - Competitors (1.2) \\
\hline
\end{tabular}


responsibility category combined, although the order of importance of responsibilities were nuanced. Conversely, the same six remaining stakeholders were considered of 'Limited' importance as moral obligations of all the companies, namely distant stakeholders (i.e. National Charity, National Sports, National Government, Any Needy), state regulators and competitors. In GFG, the first four stakeholders were ranked the same and highest (Score: 3.0) ahead of state regulators (2.0) and competitors (1.5). Both AGA and NGGL had the same order of rankings, albeit with different mean score: national charity first at a score of 2.5; national sports and national governments second at a score of 2.0; 'any needy' and state regulators next at a score of 1.5 and competitors at the very bottom of the ladder with a score of 1.0. Across cases, the rankings were national charity, national sports and national government (2.5), any needy (2.2), state regulators (1.8) and competitors (1.2). A common observation among the cases was that they all felt the least of the 'Limited' moral responsibility to do positive duty towards Competitors.

\section{Normative Moral Philosophies}

There are a number of normative arguments pertaining to the impetus for involvement in CSR activities. Discussions of these arguments constitute a bridge between apparent themes and patterns in the empirical data and identification of the moral principles underpinning involvement in CSR. The normative arguments presented here are not mutually exclusive: they dovetail into each other, and interact among each other to different extents.

\section{Owner Pre-eminence}

Whether within or between cases, the principle of shareholder pre-eminence was amply demonstrated. In the in-depth interviews for example, almost all managers intimated that their shareholders' equity or capital gave their respective companies the raison d'etre, for which reason shareholders were prioritised above any other stakeholder. Two quotes from AGA and GFG were typical:

"We don't initiate particular CSR projects just because the CEO or any other senior manager wills it. Our shareholders' investment must be protected; else we'll be violating our moral duty to seek their utmost interest...this is the least they can expect from us." (AGA Official, September, 2013).

"One can't elevate other stakeholders to the same rung on the ladder of priorities if we consider sustainability in a holistic manner. We bear in mind the fact that shareholders ... provide funds for our existence. Some of these shareholders could be as equally needy as other stakeholders are. So how moral ... uh, I mean how just or right will it be to use their resources for
CSR, especially without their prior and informed consent?" (Sustainability Official of GFG, 2013).

These quotes may not necessarily be cogent unless it came from a publicly traded company. Thus, the result did not ascertain whether the same situation would be repeated in large privately owned mining companies that are not traded on the stock market. A core argument in respect of the involvement of business entities in CSR activities has to do with the supremacy of the moral responsibility of businesses to their owners. In this regard, Lantos (2002) argues that deploying corporate resources for the social benefit of external stakeholders would be at best amoral, when the business is privately owned and immoral when it is publicly traded. Perhaps, owners of privately owned companies will have greater moral latitude to pursue altruistic CSR ventures than publicly traded ones. Also flowing from the shareholder supremacy principle is the expectation that when economic outlook become bleak, the level of commitment to CSR may be one of the first to be sacrificed, seeing that direct tax and an elaborate legal framework protects royalties, whereas CSR is only 'beyond [legal] compliance.'

\section{Stakeholder Proximity}

Moral philosophers argue that a moral agent's obligation to assist another could depend on physical proximity (Kamm, 2000) and social proximity (Nagel, 2005; Miller, 2007; Miller, 2003). It is apparent from both the analysis of the pseudo-quantitative data (Cf. Table 4), and the transcripts of in-depth interviews, that stakeholder proximity was an important basis for perceiving moral obligation to a stakeholder. For example, local charities, sports and governments evoked a higher sense of moral responsibility in the mining companies than their national (more distant) counterparts did. Managers in GFG and AGA, supported this argument when they said:

"All our stakeholders are important, but we tend to feel greater responsibility to those close to us... I think it'll be more appropriate to expect other businesses in the vicinity of distant needy persons or groups to also take up development issues in their own communities" (Sustainability Official of GFG, 2013).

"AGA and her antecedents have lived and worked in Obuasi for more than a century...Our staff have married and had children, in-laws and friends in the communities. Can we ignore them? It's only right to contribute our quota to their development. We need to seek their well-being since whatever happens to them will affect us in one way or the other." (A Supervisor in AGA, June, 2013).

Whereas the quote from the GFG official seems to dwell on physical proximity, that of AGA official clearly 
links physical proximity to social proximity - a kind of relational proximity - by citing social bonds as important considerations in 'feeling' morally obligated to provide CSR benefits to their host community. The distinction between physical and social proximities may not be practically apparent at all times. This is because it may be difficult to determine whether it is the physical closeness per se that gives rise to the social closeness as exemplified by the AGA manager's quote, or the other way round. And if there is a dynamic interaction between the two, what the extent of that interaction is (and how to tease them out for analysis) could be a daunting task.

The case firms appeared to display an even higher sense of moral obligation to their internal stakeholders. This exemplifies relational proximity. For example, shareholders, lenders and employees occupied the place of higher obligation in the stakeholder ratings than more relationally distant stakeholders like regulators and business competitors did.

Another manifestation of relational proximity is the prioritisation of Traditional Chiefs as compared to the Ghana Chamber of Mines (a business association) local government and national government. It was expected that, as a pseudo-internal stakeholder, the Chamber of Mines as an economic pressure group with enormous political influence would hold the position of priority in moral obligation among the mining companies. That traditional leadership holding the top rank in that category shows how physical and relational proximity could combine with political influence on members of host communities. This situation can be seen as a common sense modality for managing business risk from community sources, as a typical sentiment from a NGGL official will show:

\section{Community folks respect, even fear local traditional chiefs. People listen to them. We try not to provoke, but help them bring development to their communities. We've helped some of them to build or renovate their palaces and traditional monuments. In this way, we help them maintain their dignity. Dignity and honour is important to them [chiefs]. Otherwise, when there is trouble, agitation in the community, who do we fall on to bring harmony? (NGGL Official, Dec 2013).}

The power of traditional leaders was particularly felt in the more rural communities of the Ahafo area where Newmont carries out green-field operations. Newmont had invested in cultural heritage infrastructure, such as palaces and mausoleums, which directly benefitted traditional leaders. Traditional chieftains possess great influence on indigenes and tend to rein in dissenting or 'rogue' community members. Coupled with inevitably frequent interaction with the companies, traditional leaders were bound to receive high rating from the companies.
Further, between local and national government entities, the local again won the priority position on the basis of physical proximity. Again, this stance appears to be a common-sense approach to risk reduction.

Finally, the effects of relational proximity on ratings is exemplified by customers and suppliers, as proxies for upstream and downstream supply chain partners respectively. Although they were both categorised as deserving of moral responsibility, they were prioritised in 'High' and 'Limited' moral responsibility respectively.

This observation gives the impression that, as focal supply chain operating in a buyers' market, mining companies consider their customers, who ultimately convert the value created by their operations into hard cash for all stakeholders as being of greater moral priority than their suppliers are.

\section{The Slippery Slope}

Another normative moral consideration holds that mining companies, as moral agents, would refrain from getting involved in certain types of CSR initiatives to the benefit of universal stakeholders. That is to say, if we do A, we might be expected to also do B. Since we consider $\mathrm{B}$ not morally right, we will not do A to start with. This line of argument was a common dilemma among interviewee from AGA and NGGL.

This might account for the observation that even though the stakeholder 'Any Needy Anywhere' could apply to a person or group with a morally grave need and close physical proximity to the mining companies' facilities, it was still ranked one of the lowest in moral obligation. Further, observations showed that in the past, NGGL had refrained from accepting community request to tar some critically important feeder roads in Ahafo for fear that if the company shouldered such government responsibilities, community expectations will precipitate unpredictable consequences for the company, as said by an official of NGGL:

"If we start using the investments of our owners to do development projects like constructing roads, schools and other such national government-mandated works after we've paid our taxes and royalties, it becomes a challenge to convince ourselves that we're not being unfair to our shareholders. It's a real challenge because when you start, where do you stop... where do you draw the line?" (A CSR Project Officer of NGGL, December 2013).

The above argument is akin those raised by Swedish managers' position on CSR discovered by (Frederiksen 2009).

\section{Unique Resources and Competencies}

The unique resources and competences argument advocates that some corporate bodies, by virtue of their special 
human resource, special products or financial resources, were better placed than others to provide special assistance to needy groups. An example is the unique competences of an MNC operating in pharmaceutical industry to assist people living with HIV and AIDS, or a road construction company's unique competences in assisting a rural community to develop its feeder roads.

Large multinational mining companies, perceived as resource-rich, typically operate in rustic locations away from the prowling eyes of state governments. They were therefore expected to use their superior financial muscle to assist government to develop their host community or even take up community development where government is unable or inefficient in doing so, that is, acting in a 'civic republicanism' mode (Matten \& Crane, 2005). Community people frequently expressed this expectation in Focus Group and in-depth interviews:

Since Gold Fields has so much money, why can't they use some of it to develop our village into a nice place? After all, they make so much from our land. (Youth FGD, Abonte Akoon, Dec 2013).

\section{Mitigation}

Corporations that operate in high impact industries, such as mining, agriculture and pharmaceuticals, are expected to take steps to mitigate the harm their operations cause to society and the environment. This argument is based on the moral principle that says that a moral entity needs to refrain from violating the negative rights of others. In relation to the present study, all the three case mining companies displayed a high sense of moral responsibility towards the 'Adversely Affected'. Both managers and host community members variously and consistently referred to present and past losses of livelihoods as a moral basis on which they expected mining companies to be involved in CSR initiatives.

However, some government officials shared the view that replacing a polluted water source with a borehole, for example, could not be considered as CSR since it is only a compensation, as intimated by a Kumasi-based senior official of the Minerals Commission:

\section{"In the [Mineral Commission's] guidelines, it is stated that the company should engage their community stakeholders to know what kinds of development projects the communities need... [but] if mining operations destroy the only source of water available to a community and the company drills boreholes for them, then I think the boreholes do not form part of CSR. These are mere compensations" (An Engineer, Minerals Commission, October 2013).}

To justify compensatory Corporate Social Responsibility (CSR) is anomalous, or at best, not straightforward.
This is because compensations, akin to paying for goods and services, or remunerations, cannot be ordinarily classified as social responsibility in the altruistic sense. Compensations for social disruptions are within the boundaries of legal and regulatory compliance. Nevertheless, in a developing country context where the legal or quasi-legal regime is frequently weak, and enforcement critically constrained, treating compensations within the context aforementioned could be understood in 'soft law' terms, roughly worthy of a CSR cloak. This is especially so when the compensation is perceived by stakeholders as more technologically advanced that the status quo, or what communities can hope on their own.

\section{Gravity of 'Neediness'}

The weight of neediness can influence how an agency perceives moral obligations to a beneficiary. This gravity of neediness argument avers that if two or more entities have a need, the one with a greater need evokes a greater sense of moral obligation than those perceived to be with less pressing needs, other conditions remaining the same. Holding physical proximity constant, a needy charity, like a local orphanage was prioritised over a relatively wellresourced local soccer team. From Table 5, scores for the local charity ranged from $5.5-6.0$ as against $4.0-5.0$ for local sports club between and across cases. These sentiments were intimated among AGA and NGGL officials and corroborated by community stakeholders.

\section{The Moral Philosophies Underpinning CSR}

The response to the moral dilemma (i.e. supply of borehole water), and those of the stakeholders' moral prioritisation reveal that the moral theories underpinning the drivers of CSR among the mining cases under investigation do not mirror any of the four afore-mentioned orientations, except ordinary morality. First, the position of the Ethical Egoist implies that we have no moral duty to any party, or special group other than 'self' - neither in the short nor long run. In the corporate context, 'self' means the corporate ownership and the 'moral duty' is profit-maximisation. Where the corporate entity is publicly traded on the stock market, this ownership is the body of shareholders as represented, according to agency theories, by managers in their fiduciary capacity. In its purest form, the Egoist would avoid, evade or ignore laws and regulations as much as possible if doing so can be seen to maximise his profit. Where this is not possible, the egoist would adhere to the least demanding of legal compliance, or at best, address herself to the low hanging fruits of 'beyond legal compliance' positive duties. For the same reason, he may go beyond legal compliance, albeit only on an instrumental basis, in the short or long run, although the proclivity favours the short run. Further, even though the egoist would normally not give preferential treatment to any stakeholder 
other than the shareholder, he would not hesitate to do so if it will serve his interest of maximising shareholder value. This indicated that doing a positive duty is not necessarily precluded from an egoist's behavioural options. Data from both corporate and community sources indicated that the mining companies officially recognised both negative rights of their stakeholders as well as positive moral duties towards their communities, a dual position Egoists would not take.

For the latter reasons, it would appear very difficult to determine if a particular initiative was based on selfinterest. This was because the three top-most drivers of the companies' CSR initiatives were the need to gain and maintain 'Company Reputation', 'Pre-empting [harsh] Regulations' and the opportunity to contribute to 'Local Development Plans.' Even though the first two appear to be self-serving in nature, it was also observed that 'Local Development Plans' was among the top-most. Results of the Potable Water Scenario and Stakeholder Responsibilities showed moral responsibilities towards external stakeholders were also among the 'High' moral responsibility ratings, and indicative of the position that the companies' CSR were not underpropped by Egoism.

Second, to be driven by libertarian moral principles, the companies must feel obliged to preserve the negative duty of not violating the rights of persons who directly bore the blunt of the externalities of the mining companies' operations such as land-take, environmental and noise pollution. Indeed, this was clearly observed in the Stakeholders Moral responsibility analysis where companies felt great responsibility towards persons adversely affected by their operations. In each company, however, internal stakeholders, (i.e.; shareholders and lenders for GFG and NGGL; and employees for AGA) were prioritised above 'adversely affected'. In order to be libertarian, the companies would not display any preferential treatment of stakeholders since they would not 'feel' any moral responsibility for doing positive good to any external stakeholder far or near. Of course, there would be no talk of 'weight of moral stake' on the basis of magnitude of total happiness, if the CSR involvement of any of the mining companies were based on libertarianism. Therefore, the evidence did not support a libertarian philosophy.

A third alternative, utilitarianism, is a more demanding moral position. It avers that a moral agent must decide in favour of a moral choice that maximises the total sum of the happiness of all human beings, considered from an impartial perspective. Both the Potable Water scenario and the 'Stakeholder' analysis show clear preferential treatment for stakeholders on the basis of physical and social proximity, among others. If the companies had opted to assist the relatively large numbers of potential beneficiaries regardless of the physical or social proximities to the companies' physical facilities, one would have considered the possibility of the companies deciding on utilitarian moral principles. As it turned out to be, the utilitarian morality stands to be inadmissible as the moral foundation of the CSR policies of the case mining companies on the foregoing analytical basis.

Finally, the possibility of a Common Sense morality as the plausible ethical bedrock of the case mining companies' CSR policies is considered. A cursory look at the Potable Water scenario and the Stakeholder moral responsibility all will point to Kagan's (1989) 'ordinary morality' regarding both negative rights and positive duties. This was demonstrated by all three cases in that they prioritised internal stakeholders above external ones. They also elevated proximate stakeholders above distant ones. This discrimination among stakeholders shows that besides their moral responsibility not to violate anyone's rights, companies also accepted responsibilities for positive duties, albeit towards special groups in accordance with their immediate 'moral intuitions' as moral agents. In a nutshell, only the 'Common-Sense Morality' theoretical position was amply supported. Thus, both kinds of goal-oriented or instrumental teleological moral theories, (i.e., egoism and utilitarianism) could not be upheld. On the contrary, a duty-based deontological moral theory was found to be the most likely basis of all three mining companies' CSR policies and strategies. It was further determined that their moral foundations were based more on morally demanding (i.e. common-sense) principles than minimalistic ones (i.e., libertarianism).

This conclusion is at variance with Premeaux and Mondy (1993) and Premeaux (2004) who found that managers' ethical decisions were based on Utilitarian principles. It is however in consonance with Frederiksen (2009) finding on the matter. This distinction within the deontological set of moral theories is critical to the extent that it is expected to have a major impact on the design of the companies' CSR policies, and the strategies emanating from them. A morally demanding duty-based foundation would normally be expected to spur policies and strategies which demonstrate greater social investment which will in turn engender a greater community development.

\section{The Influence of Moral Foundations on CSR Strategies}

Based on CSR strategies proposed by Lantos (2002), the mining companies seem to opt for one of four CSR strategies: pure profit-maximisation, constrained profitmaximisation, social activism and pure altruism. The last two of these strategies were not in contention, since they must be underpinned by moral principles of moderate and high degrees of utilitarianism respectively. Pure profit-maximisation does not explain the observations made either, in that it is based mainly on Egoism. Pure 
and moderate profit-maximisation could sit well with Lantos' (2001, 2002) strategic CSR policy. However, since the companies amply demonstrated a clear concern for their respective host community in the preceding analysis, the pervading plausible CSR policies among the mining companies would suggest a strong leaning towards constrained profit-maximisation.

\section{Implications of Findings}

The foregoing empirical findings have implications for policy and practice regarding the design and implementation of CSR-mediated initiatives in mining communities. A major policy of the mining communities has been the use of community consultative committees as a fulcrum around which corporate-community engagements have revolved. An understanding of industrial miners' ethical philosophies and how these impinge on their CSR strategies is expected to inform corporate-community engagement, which might in turn determine the socioeconomic outcomes of CSR initiatives. Further, a good understanding of the key drivers of CSR in a developing world context will imply that host communities and governments can better negotiate better 'deals' with mining companies. For example, knowing that a pre-existing local-level development plan id a strong driver of CSR will mean that local government authorities and traditions chieftains should put more into developing such plans and providing the development engagement space therein for the use of mining and similar companies.

\section{Conclusions}

Three main conclusion can be drawn from the study. First, the strongest drivers of CSR among large-scale mining firms operating in Ghana are their need to procure, protect and promote company reputation; the desire to pre-empt stiffer state regulation; and the encouragement of pre-existing of development plans for host communities. Moderately strong drivers were related to expectations and agitations of various internal and external stakeholders; fear of state sanctions; and industry peer pressure and mimicry, in descending order of importance.

Second, beside their heightened sense of moral obligation towards shareholders (i.e. this is a demonstration of owner primacy), the case mining companies tended to demonstrate greater sense of moral responsibility towards stakeholders who were geographically and/or relationally closer to their facilities than similar but distant ones.

Finally, pragmatic Common-Sense morality underpins the CSR strategies of the large-scale mining companies in Ghana. Unlike the teleological egoistic self-interest commonly associated with business entities, the Common-Sense philosophy is a deontological philosophy from which a demanding economic strategy of constrained profit-maximisation emerges.

\section{Limitations of the Study}

Interviews were mostly conducted in the local Akan dialect(s), while the interview protocols were prepared in English. This meant the accuracy of respondent understanding stood the risk of being compromised. The researcher's proficiency in these languages minimised interviewee confusion and misunderstanding. The researcher also conducted all in-depth interviews and moderated all FGDs; and ensured that immediate feedbacks of summaries of FGDs were given to participants to ascertain the accuracy of information captured. Further, the use of interview and discussion guides made the work prone to weaknesses commonly associated with subjectivity.

Low questionnaire return rates are common in Ghana, especially from busy corporate executives, threatened to reduce the quality and quantity of data. To limit these potential drawbacks, the researcher personally delivered, conducted and collected the questionnaires. Efforts were also made to discover the cultural 'ways and means' of target institutions (especially, companies and traditional authorities) so as to be effective in negotiating access to information sources.

CSR is still considered an emerging field of knowledge. In analysing data gathered by means of qualitative interviews, there is the danger of imposing a theoretical framework on the data which may be culturally inappropriate. The multi-stakeholder approach adopted by this study, despite its few drawbacks, was considered appropriate for the Ghanaian social context, where social norms encourage altruistic communalism.

\section{Abbreviations}

AfDB: African Development Bank; AGA: AngloGold Ashanti Ltd;

AIDS: Acquired Immune Deficiency Syndrome; CEO: Chief Executive Officer;

CSR: Corporate Social Responsibility; FGD: Focus group discussion;

GCM: Ghana Chamber of Mines; GEITI: Ghana Extractive Industries

Transparency Initiative; GFG: Gold Fields Ghana Ltd; GMl: Global Mining Initiative; HIV: Human Immunodeficiency Virus; IBLF: International Business Leadership Forum; MNC: Multinational Corporation; NGGL: Newmont Ghana Gold Ltd; UK: United Kingdom; US\$: Unites States dollar; WBCSD: World Business Council for Sustainable Development

\section{Acknowledgements}

Not application.

\section{Funding}

Not applicable.

\section{Availability of data and materials}

Not sharing; because primary data included in manuscript.

Authors' contributions

All authors read and approved the final manuscript.

\section{Authors' information}

Richard K. Boso is a PhD candidate at Kwame Nkrumah University of Science and Technology (KNUST), Kumasi, Ghana, and an adjunct lecturer in Supply Chain Management at GIMPA (Ghana Institute Management and Public Administration).

Prof Sam K. Afrane was Provost of the College of Art and Social Sciences at Kwame Nkrumah University of Science and Technology (KNUST), Kumasi, 
Ghana. He is currently the President and CEO of the Christian Service University College, Kumasi.

Prof Daniel K. B. Inkoom is the Head of Department of Planning at Kwame Nkrumah University of Science and Technology (KNUST), Kumasi, Ghana.

\section{Competing interests}

Not applicable.

\section{Consent for publication}

Not applicable.

\section{Ethics approval and consent to participate}

Not applicable.

\section{Publisher's Note}

Springer Nature remains neutral with regard to jurisdictional claims in published maps and institutional affiliations.

Received: 24 February 2017 Accepted: 2 June 2017

Published online: 24 June 2017

\section{References}

ActionAid. (2006). Gold Rush: The Impact of Gold Mining on Poor People in Obuasi in Ghana. Johannesburg: ActionAid International.

AGA (2007). Country report Ghana Obuasi 2006, Accra: AngloGold Ashanti.

Albrechtsen, J. (2006). This business of moral coercion is just a hoax, The Australian, 29

Amaeshi, K. M., Adi, B. C., Ogbechie, C., \& Olufemi, O. A. (2006). Corporate social responsibility in Nigeria: western mimicry or indigenous influences?'. Journal of Corporate Citizenship, 24(Winter), 83-99.

APA (American Psychological Association), (2010). Ethical principles of psychologists and code of conduct. [Retrieved from http://www.apa.org/ ethics/code/principles.pdf, Accessed 3 Jan 2012].

Arko, B. (2013). Corporate social responsibility in the large scale gold mining industry in Ghana. Journal of Business and Retail Management Research, 8(1), $81-90$.

Aryeetey, E., Osei, B., Laryea, A. D. A., Antwi-Asare, T. O., Baah-Boateng, W., Turkson, E., Cudjoe, E. \& Ahortor, C. (2005). Globalisation, employment and poverty reduction - A case study of Ghana, Report of a Study Commissioned by the International Labour Organisation (ILO), Accra: Institute of Statistical, Social and Economic Research (ISSER), University of Ghana, Legon.

Aryeetey, E., Osei, B. \& Twerefou, D. K. (2004). Globalisation, employment and livelihoods in the mining sector of Ghana, 1980-2002, Monographic Report, Accra: Institute of Statistical, Social and Economic Research (ISSER), University of Ghana, Legon.

Australian Government. (2006). Corporate responsibility: managing risk and creating value, paper presented to the parliamentary joint committee on corporations and financial services. Canberra: Commonwealth of Australia.

Blowfield, M. (2003). Ethical supply chains in the cocoa, coffee and tea industries. Greener Management International, 43, 15-24.

Blowfield, M., \& Frynas, J. G. (2005). Setting new agendas: critical perspectives on corporate social responsibility in the developing world. International Affairs, 81(3), 499-513

Boon, E. K. \& Ababio, F. (2009). Corporate social responsibility in Ghana: Lessons from the mining sector, IAIA09 Conference Proceedings: Impact Assessment and Human Well-Being, 29th Annual Conference of the International Association for Impact Assessment, Held on 16-22 May 2009, Accra, Ghana

Bourdieu, P. (1992). "The practice of reflexive sociology", in P. Bourdieu and Wacquant, L. J. D. (Eds.), An invitation to reflexive sociology, Chicago: The University of Chicago Press, pp. 217-260.

Capaldi, N. (2016). New (Other?) Directions in Corporate Social Responsibility, International Journal of Corporate Social Responsibility, (1): 4, doi:10.1186 s40991-016-0005-5

Cavanagh, G. F., Moberg, D. J., \& Velasques, M. (1981). The ethics of organisational politics. Academy of Management Review, 6(3), 363-374.

Chatterjee, B., \& Mitra, N. (2017). CSR should contribute to the national agenda in emerging economies - the 'Chatterjee Model'. International Journal of Corporate Social Responsibility, 2, 1. doi:10.1186/s40991-017-0012-1.

Crane, A., \& Matten, D. (2007). Business Ethics (2nd ed.). Oxford: Oxford University Press.
Creswell, J. W. (2007). Qualitative inquiry and design: Choosing among five approaches (2nd ed.). Thousand Oaks, CA: Sage Publications, Inc.

Denzin, N. K. \& Lincoln, Y. S. (1994). Handbook of Qualitative Research, London: Sage Publications, Inc.

Effah-Gyamfi, K. (1979). Traditional History of the Bono State, Accra: Institute of African Studies, University of Ghana, Legon.

Frederiksen, C. S. (2009). The Relation between policies concerning corporate social responsibility (CSR) and philosophical moral theories (An empirical investigation, CSR \& Business in Society (CBS) Working Paper No. 03-2009). Frederiksberg, Denmark: CBS Centre for CSR.

Friedman, M. (1970). The social responsibility of business is to increase its profits, New York Times Magazine, September 13

Fritzsche, D. J., \& Becker, H. (1984). Linking management behaviour to ethical philosophy - An empirical investigation. Academy of Management Journal, 27(1), 166-175.

Frynas, J. G. (2005). The false developmental promise of corporate social responsibility: evidence from multinational oil companies. International Affairs, 81(3), 581-598.

Gardiner, L., Rubbens, C. \& Bonfiglioli, E. (2003). Research, big business and big responsibility", Corporate Governance, 3(3), 67-77.

Garriga, E., \& Mele, D. (2004). Corporate social responsibility theories: Mapping the territory. Journal of Business Ethics, 53, 51-74.

Garvey, N., \& Newell, P. (2005). Corporate accountability to the poor? Assessing the effectiveness of community-based strategies. Development in Practice, 15(3-4), 389-404.

GCM (Ghana Chamber of Mines). (2008a). Publish what you pay - 2008. Accra: Ghana Chamber of Mines.

GCM (Ghana Chamber of Mines). (2008b). The Ghana Chamber of Mines Factoid 2008. Accra: Ghana Chamber of Mines.

GCM (Ghana Chamber of Mines). (2012). The Ghana Chamber of Mines Factoid 2011. Accra: Ghana Chamber of Mines.

GCM. (2014). The Ghana Chamber of Mines Factoid 2013. Accra: Ghana Chamber of Mines.

GFG (2014). Gold Fields Ghana Ltd Annual Report 2014, Accra: Gold Fields Ghana Ltd.

Ghana Minerals Commission (2010). Geology and mineral deposits, [Retrieved from http://www.ghanamining.org/ghweb/en/ma/mincom/mcminingnews.html, Accessed 8 Aug 2010].

Gough, K. V., \& Yankson, P. W. K. (2012). Exploring the connections: mining and urbanisation in Ghana. Journal of Contemporary African Studies, 30(4), 651-668. doi:10.1080/02589001.2012.724867.

Govindan, K., Kannan, D., \& Shankar, M. (2014). Evaluating the drivers of corporate social responsibility in the mining industry with multi-criteria approach: A multi-stakeholder perspective. Journal of Cleaner Production, 84, 214-232.

Graham, D., \& Woods, N. (2006). Making corporate self-regulation effective in developing countries. World Development, 34(5), 868-883.

GSS (2012). 2010 [Ghana] Population and housing census: Summary report of final results, Accra: Ghana Statistical Service.

Henderson, D. (2001). Misquided Virtue: False Notions of Corporate Social Responsibility. London: Institute of Economic Affairs.

Hilson, A. E. (2014). Resource Enclavity and Corporate Social Responsibility in SubSaharan Africa: The Case of Oil Production in Ghana, Unpublished Ph.D. Thesis, Aston University, UK. https://research.aston.ac.uk/portal/services/download Register/14960099/Hilson_Abigail_2014.pdf, Accessed 25 Dec 2015.

Howe, K. R. (1992). Getting over the quantitative-qualitative debate. American Journal of Education, 100, 236-256.

Howe, K. R. (1988). Against the quantitative-qualitative incompatibility thesis, or, dogmas die hard. Educational Researcher, 17, 10-16.

Husted, B., \& de Jesus Salazar, J. (2006). Taking Friedman seriously: maximising profits and social performance. Journal of Management Studies, 43(1), 75-91.

IBLF. (2002). Building a shared future: The role of business as a partner in African development. London: International Business Leadership Forum (IBLF).

Imani Development, (2009). Corporate social responsibility in Sub-Saharan Africa - built in or bolted on? a survey on promoting and hindering factors, Eschborn, Germany: Deutsche Gesellschaft für Technische Zusammenarbeit [GTZ] GmbH \& British High Commission, South Africa

IMF (2015). World Economic Outlook Database, April 2015, Washington DC: International Monetary Fund.

Ismail, M. (2009). Corporate social responsibility and its role in community development: an international perspective. Journal of International Social Research, 2(9), 199-209.

Jenkins, R. (2005). Globalisation, corporate social responsibility and poverty. International Affairs, 81(3), 525-540. 
Jones, T. M. (1980). Corporate social responsibility revisited, redefined. California Management Review, 22(2), 59-67.

Kagan, S. (1989). The Limits of Morality. Oxford: Oxford University Press.

Kamm, F. M. (2000). Does distance matter morally to the duty to rescue. Law and Philosophy, 19, 655-681.

Kemp, D., Owen, J. R. \& van de Graaff, S. (2012). "Corporate social responsibility, mining and 'audit culture',', Journal of Cleaner Production, 24, 1-10.

Klempner, G. (2006). Philosophy of CSR, Philosophy for Business, Issue 27, 17

Kurucz, E. C., Colbert, B. A. \& Wheeler, D. (2008). The business case for corporate social responsibility", In Crane, A., McWilliams, A. Matten, D. Moon, J. \& Seigel, D. (Eds.) The Oxford handbook on corporate social responsibility, Oxford: Oxford University Press, 83-112.

Lantos, G. P. (2002). The ethicality of altruistic corporate social responsibility. Journal of Consumer Marketing, 19(3), 205-230.

Lantos, G. P. (2001). The boundaries of strategic corporate social responsibility. Journal of Consumer Marketing, 18(7), 595-630.

Manteaw, B. (2007). From tokenism to social justice: rethinking the bottom line for sustainable community development. Community Development Journal, 43(4), 428-443.

Matten, D., \& Crane, A. (2005). Corporate citizenship: toward an extended theoretical conceptualisation. Academy of Management Review, 30(1), $166-179$

Matten, D., \& Moon, J. (2008). 'Implicit' and 'explicit' CSR: A conceptual framework for a comparative understanding of corporate social responsibility. Academy of Management Review, 33(2), 404-424.

Miles, M. B., \& Huberman, A. M. (1994). Qualitative data analysis - An expanded sourcebook (2nd ed.). Thousand Oaks, CA: Sage Publications, Inc.

Miller, D. (2007). National responsibility and global justice. Oxford: Oxford University Press.

Miller, R. W. (2003). Moral closeness and world community, in Chatterjee, D. K (ed.), The ethics of assistance: morality and the distant needy London: Cambridge University Press, 101-122.

Miller, T. R., Baird, T. D., Littlefield, C. M., Kofinas, G., Chapin, F., III, \& Redman, C. L. (2008). Epistemological pluralism: reorganizing interdisciplinary research. Ecology and Society, 13(2), 46.

Mkansi, M., \& Acheampong, E. A. (2012). Research philosophy debates and classifications: students' dilemma. The Electronic Journal of Business Research Methods, 10(2), 132-140

Moon, J. (2002a). Corporate social responsibility: an overview. In C. Hartley (Ed.), The International Directory of Corporate Philanthropy (pp. 3-14). London: Europa Publications.

Moon, J. (2002b). Business social responsibility and new governance. Government and Opposition, 37(3), 385-408

Moon, J., Crane, A., \& Matten, D. (2005). Can corporations be citizens? Corporate citizenship as a metaphor for business participation in society. Business Ethics Quarterly, 15(3), 427-451.

Muthuri, J. (2007). Participation and accountability in corporate community involvement programs: A research agenda. Community Development Journal, 43, 177-193

Nagel, T. (2005). The problem of global justice. Philosophy \& Public Affairs, 33(2), 113-147.

Nguyen-Thanh, D., \& Schnell, M. (2009). Reviewing half a decade of EITI implementation in Ghana's mining sector. In C. Eads, P. Mitchell, \& F. Paris (Eds.), Advancing the EITI in The Mining Sector: A Consultation with Stakeholders (pp. 50-54). Oslo: Extractive Industries Transparency Initiative.

Nozick, R. (1974). Anarchy, state and utopia. Oxford: Blackwell Publishing Ltd.

Ofori, D. F., \& Hinson, R. E. (2007). Corporate social responsibility perspectives of leading firms in Ghana. Corporate Governance, 7(2), 178-193.

Prasad, B. C. (2004). Globalisation, free trade and corporate citizenship in pacific forum island countries. Journal of Corporate Citizenship, 13, 65-76.

Premeaux, S., \& Mony, W. (1993). Linking management behaviour to ethical philosophy. Journal of Business Ethics, 12, 349-357.

Premeaux, S. (2004). The current link between management behaviour and ethical philosophy. Journal of Business Ethics, 52, 269-278.

Reidenbach, R. E., \& Robin, D. P. (1990). Towards the development of a multidimensional scale for improving evaluations of business ethics. Journal of Business Ethics, 9, 639-653.

Saunders, M., Lewis, P., \& Thornhill, A. (2007). Research Methods for Business Students (5th ed.). Harlow, England: Pearson Education Ltd.

Singer, P. (1970). Famine, affluence, and morality. Philosophy and Public Affairs, 1(3), 229-243.
Smart, J. J. C. (1973). An outline of a system of utilitarian ethics. In J. J. C. Smart \& B. Williams (Eds.), Utilitarianism: For and Against. London: Cambridge University Press.

SustainAbility. (2004). Gearing Up: From corporate responsibility to good governance and scalable solutions. London: SustainAbility.

Tashakkori, A., \& Teddlie, C. (1998). Mixed methodology: Combining research: qualitative and quantitative approached. Thousand Oaks, CA: Sage Publications, Inc.

Tavakol, M. \& Dennick, R. (2011). "Making sense of Cronbach's Alpha", Intl. Journal of Medical Educ., 2: 53-55.

Temeng, V. A., \& Abew, J. K. (2009). A review of alternative livelihood projects in some mining communities in Ghana. European Journal of Scientific Research, 35(2), 217-228.

Transparency International. (2005). Global Corruption report 2005. Berlin: Transparency International.

Utting, P. (2005). Corporate responsibility and the movement of business. Development in Practice, 15(3-4), 375-388.

van Marrewijk, M. (2003). Concepts and definitions of CSR and corporate sustainability: between agency and communion. Journal of Business Ethics, 44(2/3), 95-105.

Visser, W. (2005a). Corporate citizenship in South Africa: a review of progress since democracy. Journal of Corporate Citizenship, 18, 29-38.

Visser, W. (2005b). Is South Africa world class in corporate citizenship? In A. Freemantle (Ed.), The Good Corporate Citizen. Johannesburg: Trialogue.

WBCSD. (2000). Corporate social responsibility: Making good business sense. Geneva: The World Business Council for Sustainable Development.

WBCSD (2002). The business case for sustainable development, Geneva: The World Business Council for Sustainable Development.

Yankson, P. W. K. (2010). Gold mining and corporate social responsibility in the Wassa West district, Ghana. Development in Practice, 20(3), 354-366. doi:10. 1080/09614521003709965.

Yelpaala, K. \& Ali, S. H. (2005). "Multiple scales of diamond mining in akwatia, ghana: addressing environmental and human development impact", Resources Policy 30: 145-155.

Yin, R. K. (2003). Case study research: Design and methods, 3rd ed., Thousand Oaks, CA: Sage Publications, Inc.

\section{Submit your manuscript to a SpringerOpen ${ }^{\circ}$ journal and benefit from:}

- Convenient online submission

- Rigorous peer review

- Open access: articles freely available online

- High visibility within the field

Retaining the copyright to your article

Submit your next manuscript at $>$ springeropen.com 